\title{
Respiratory status and allergy after bronchiolitis
}

\author{
M Murray, M S C Webb, C O'Callaghan, A S Swarbrick, A D Milner
}

\begin{abstract}
As part of a long term prospective study, 73 children who had been admitted to hospital with viral bronchiolitis as infants, were reviewed 5.5 years later and compared with a carefully matched control group. In the postbronchiolitis group, there was a highly significant increase in respiratory symptoms including wheezing $(42.5 \% v 15.0 \%$, relative risk $=2 \cdot 8$ ).

Although atopy in the family was not significantly increased in the index group, personal atopy was more prevalent. However, personal atopy was not significantly more prevalent in the symptomatic postbronchiolitis, compared with those who were symptom free, and so did not account for the high prevalence of postbronchiolitis wheezing in this cohort. In addition, in a stepwise logistic regressional model, bronchiolitis remained a significant predictor of wheezing after adjusting for potential confounding variables, including atopy. Bronchial responsiveness to histamine was significantly increased in the index group. However, no significant relationship of positive tests to wheezing could be demonstrated, and a high rate of positive responses was noted in the controls.
\end{abstract}

There have been many follow up studies of children who have acute bronchiolitis in infancy. All are agreed that these children are more likely to experience respiratory symptoms, particularly coughing and wheezing, compared with the normal population. Although more prevalent, these symptoms have varied in severity ${ }^{1-3}$ and have tended to diminish with time. ${ }^{45}$ Our own long term prospective study of bronchiolitis has shown that $75 \%$ experienced wheezing in the first two years after the illness 6 and $59 \%$ were still having wheezing episodes 3.5 years later. ${ }^{7}$ What remains unclear is whether viral bronchiolitis per se causes increased airways lability $^{48}$ or whether those children with a genetic predisposition to atopy are more likely to develop bronchiolitis and/or postbronchiolitis symptoms. Previous studies looking at this issue have mostly been retrospective and have involved a single follow up study many years later, ${ }^{1} 3489-14$ thus potentially resulting in problems of recall bias. In some instances, follow up has been at a variable time interval since the illness and sometimes a control group has not been included. ${ }^{19-12} 15$ The findings have been contradictory on the role of atopy, ${ }^{1414} 16-18$ and have suggested that environmental factors such as family size, ${ }^{4} 1319$ parental smoking, ${ }^{19182021}$ breast feeding, ${ }^{13} 19$ and neonatal respiratory illness ${ }^{18} 19$ may be contributing to either the initial illness, subsequent symptoms, or both. There are also claims that bronchiolitis in infancy contributes to chronic airways obstruction in adult life. ${ }^{22-24}$ In order to investigate these aspects further, we have reassessed the same cohort ${ }^{7} 5 \cdot 5$ years after the illness and compared these children with a carefully matched control group and report the findings in this paper.

\section{Patients and methods}

One hundred and one patients were recruited on admission to the Queen's Medical Centre, Nottingham, during the winter epidemics of respiratory syncytial virus (RSV) infection in 1979, 1980, and 1981. The criterion for entry was the clinical diagnosis of acute bronchiolitis in a child with no history of a previous similar illness. All had cough, tachypnoea, and feeding difficulties associated with hyperinflation, recession, fine crepitations, and often rhonchi. The mean age at the time of admission was 113 days (range 25-343), and in those followed up 5.5 years later was 103 days (range $25-343$ ). The first 21 children enrolled for the study were those whose illness was severe enough to preclude oral feeding. All subsequent admissions irrespective of severity were considered eligible. The original cohort included 54 males and 47 females, of whom $57 / 86(66 \%)$ were RSV positive. This was assessed by immunofluorescence, tissue culture, or both. Of those followed up 5.5 years later, $42 / 62(68 \%)$ of those with available results, were RSV positive.

The controls were recruited by obtaining roll lists from the schools in the catchment area of the hospital and matching each index child in terms of birth date, sex, race, area, and maternal smoking. The most important exclusion criterion for the controls was when it was not known whether they had suffered from acute bronchiolitis in the first year of life. Therefore children who had required admission to hospital in infancy with a diagnosis of acute bronchiolitis or required visits to their general practitioner for an ongoing respiratory problem in infancy, were not included in the control group. A history was taken from the mother with emphasis on details of upper and lower respiratory tract symptoms over the preceding year.

The family history of asthma, eczema, or hayfever was recorded, as were manifestations of atopy in the child such as eczema and allergies. The children were examined and recordings of height and weight were taken. 
Table 1 Clinical details, and social and family characteristics

\begin{tabular}{|c|c|c|c|}
\hline & Bronchiolitis & Control & p Value \\
\hline \multirow{7}{*}{$\begin{array}{l}\text { Mean (SD) birth weight (g) } \\
\text { No (\%) birth weight } \\
<2500 \mathrm{~g} \\
<2000 \mathrm{~g} \\
\text { Mean (SD) gestation (weeks) } \\
\text { No (\%) <37 weeks } \\
\text { No (\%) breast fed } \\
\text { Mean (range) length of breast feeding (weeks) } \\
\text { Follow un: }\end{array}$} & $3040(630)$ & $3160(600)$ & NS \\
\hline & $13(7 \cdot 8)$ & $7(9 \cdot 6)$ & NS \\
\hline & $\begin{array}{l}2(2 \cdot 7) \\
39 \cdot 1(2 \cdot 2)\end{array}$ & $\begin{array}{l}5(6 \cdot 8) \\
39 \cdot 6(1 \cdot 6)\end{array}$ & $\begin{array}{l}\text { NS } \\
\text { NS }\end{array}$ \\
\hline & $7(9 \cdot 6)$ & $7(9 \cdot 6)$ & NS \\
\hline & $30(41 \cdot 1)$ & $27(37 \cdot 0)$ & NS \\
\hline & $8 \cdot 7(0 \cdot 5-36)$ & $8 \cdot 3(0 \cdot 5-26)$ & NS \\
\hline & \\
\hline Mean (SD) weight (kg) & $20 \cdot 4(3.4)$ & $21 \cdot 2(2 \cdot 8)$ & NS \\
\hline Median weight centile & & & \\
\hline Mean (SD) height (cm) & $113 \cdot 7(5 \cdot 4)$ & $115 \cdot 9(4 \cdot 9)$ & $\mathrm{p}<0.05$ \\
\hline \multirow{3}{*}{\multicolumn{4}{|c|}{$\begin{array}{l}\text { Family: } \\
\text { Mean (range) No of siblings }\end{array}$}} \\
\hline & & & \\
\hline $\begin{array}{l}\text { Mean (range) No of siblings } \\
\text { Total }\end{array}$ & & & \\
\hline $\begin{array}{l}\text { lotal } \\
\text { Older }\end{array}$ & $\begin{array}{l}1.9(0-6) \\
1.4(0-6)\end{array}$ & $1.8(0-6)$ & NS \\
\hline \multicolumn{4}{|l|}{ No (\%) parents who smoke } \\
\hline Mothers & $40(54 \cdot 8)$ & $41(56 \cdot 2)$ & NS \\
\hline $\begin{array}{l}\text { Fathers } \\
\text {. }\end{array}$ & $35(47 \cdot 9)$ & $39(53 \cdot 4)$ & NS \\
\hline \multicolumn{4}{|l|}{ No (\%) social class: } \\
\hline 1,2 & $\begin{array}{l}7(9 \cdot 6) \\
35(47 \cdot 9)\end{array}$ & $\begin{array}{l}3(4 \cdot 1) \\
32(43 \cdot 8)\end{array}$ & \\
\hline 4 & $9(12 \cdot 3)$ & $11(15 \cdot 1)$ & NS \\
\hline 5 and unclassified ${ }^{*}$ & $22(30 \cdot 1)$ & $27(37 \cdot 0)$ & \\
\hline
\end{tabular}

${ }^{*}$ Unclassified $=$ unemployed, disabled, single parent family.

Skin tests were performed using the epicutaneous prick method ${ }^{25}$ with three Bencard solutions - cat fur, house dust mite, and B2 grass pollens-along with a positive (histamine) and negative (saline) control. The weal diameter was measured at 15 minutes and a reading of $3 \mathrm{~mm}$ or more was regarded as positive. Lung function tests were performed using a PK Morgan spirometer and forced expiratory volume in 0.75 and 1 second $\left(\mathrm{FEV}_{0.75}, \mathrm{FEV}_{1}\right)$ and maximum expiratory flow $\left(\dot{V}_{\text {max }}\right)$ were recorded after an initial training period. A histamine challenge was performed where $\dot{V}_{\max }$ was reproducible over three successive attempts. The technique described by Cockroft et al was adopted after dilution by buffered histamine acid phosphate in doubling concentrations from 0.25 to $8 \mathrm{mg} / \mathrm{ml} .{ }^{26}$ The provocative concentration of histamine required to cause a greater than $20 \%$ fall in $V_{\max }$ was recorded and the $\mathrm{PC}_{20}$ calculated.

\section{STATISTICAL ANALYSIS}

Results were analysed using the $\chi^{2}$ test (with Yates's correction when $\mathrm{n}<100$ ) for categorical variables, and the Fisher's exact test was used when the expected frequency for any cell was less than 5 . The unpaired $t$ test was used for continuous variables and the Mann-Whitney $\mathrm{U}$ test for variables that were not normally distributed and for some grouped data (height and weight centiles). The BMPD statistical package for stepwise logistic regression was used to assess whether the bronchiolitis/wheeze relationship remained significant after taking account of potentially confounding variables.

\section{ETHICS}

The study was ethically approved by the hospital ethics committee and written informed consent was obtained from the parents.

\section{Results}

Twenty eight children were lost to follow up. Of these, 21 had moved out of the area or had been lost to follow up despite repeated letters and telephone calls. Seven children were excluded: four because of major neurological illnesses, one because of congenital heart disease, and two on the basis that the original diagnosis was doubtful. Thus, 73 children, 36 males and 37 females, were seen at a mean age of 71 months (range 67-83 months) and a mean time since the illness of 67 months (range $65-78$ months). The 73 controls were seen at a mean age of 75 months (range 68-74 months); thus, they were on average 4 months older than the index children when seen. The children in both groups were analysed according to clinical details along with social and family characteristics (table 1). The mean birth weight and gestation were not significantly different and there was no difference with respect to the frequency or duration of breast feeding. At the follow up visit, index children tended to weigh less and were significantly shorter than controls. However, when adjustment was made for the age difference between the two groups, there was no difference in their respective growth centiles. The mean number of siblings was not different, although index children had significantly more older siblings. The social class profile of the two groups was very similar. The groups were closely matched for maternal smoking, thus $55 \%$ of index children had mothers who smoked compared with $56 \%$ of controls. Paternal smoking was similar in the two groups.

At follow up $42 \cdot 5 \%$ of the postbronchiolitis children reported wheezing episodes over the previous year compared with $15 \cdot 1 \%$ of the controls, giving a relative risk for wheezing 5.5 years after the illness of $2 \cdot 8$ (table 2 ). Coughing episodes were reported in $65.8 \%$ of the index children and $37 \%$ of the controls, with a relative risk for postbronchiolitis of $1 \cdot 8$. With both symptoms, the differences between the two groups were highly significant (table 2). All of the children who reported wheezing episodes

Table 2 Respiratory symptoms, medication, and general practitioner consultations in the previous year. Figures are number (\%) in each group, unless otherwise stated

\begin{tabular}{|c|c|c|c|c|}
\hline & $\begin{array}{l}\text { Bronchiolitis } \\
(n=73)\end{array}$ & $\begin{array}{l}\text { Controls } \\
(n=73)\end{array}$ & $\begin{array}{l}\text { Relative } \\
\text { risk }\end{array}$ & $p$ Value \\
\hline $\begin{array}{l}\text { Wheeze } \\
\text { Coughing episodes } \\
\text { Medication for episodes of cough/wheeze: }\end{array}$ & $\begin{array}{l}31(42 \cdot 5) \\
48(65 \cdot 8)\end{array}$ & $\begin{array}{l}11(15 \cdot 1) \\
27(37 \cdot 0)\end{array}$ & $\begin{array}{l}2 \cdot 8 \\
1 \cdot 8\end{array}$ & $\begin{array}{l}\mathrm{p}<0.001 \\
\mathrm{p}<0.001\end{array}$ \\
\hline $\begin{array}{l}\text { Cough linctus } \\
\text { Bronchodilators } \\
\text { Prophylactics } \\
\text { Antibiotics } \\
\text { Mean (range) No of URTI } \\
\text { Recurrent nasal blockage or discharge } \\
\text { Mean (range) No visits by general practitioner }\end{array}$ & $\begin{array}{l}10(13 \cdot 7) \\
24(32 \cdot 9) \\
7(9 \cdot 6) \\
28(38 \cdot 4) \\
3 \cdot 8(0-12) \\
25(34 \cdot 2) \\
1 \cdot 7(0-10)\end{array}$ & $\begin{array}{l}8(11 \cdot 0) \\
4(5 \cdot 5) \\
3(4 \cdot 1) \\
17(23 \cdot 3) \\
2 \cdot 7(0-12) \\
8(11 \cdot 0) \\
1 \cdot 1(0-8)\end{array}$ & $\begin{array}{l}1 \cdot 3 \\
6 \cdot 0 \\
2 \cdot 3 \\
1 \cdot 6 \\
\overline{3 \cdot 1} \\
-\end{array}$ & $\begin{array}{l}\text { NS } \\
p<0.0001 \\
\text { NS } \\
p<0.05 \\
p<0.05 \\
p<0.001 \\
p<0.05\end{array}$ \\
\hline
\end{tabular}


Table 3 Personal and family history of atopy. Figures are number (\%)

\begin{tabular}{|c|c|c|c|}
\hline & Bronchiolitis & Controls & p Value \\
\hline $\begin{array}{l}\text { Family history of asthma in first degree relative } \\
\text { Family history of asthma, eczema, }\end{array}$ & $18(24 \cdot 7)$ & $18(24 \cdot 7)$ & NS \\
\hline $\begin{array}{l}\text { or hayfever in first degree relative } \\
\text { Personal history of eczema } \\
\text { Positive skin tests: }\end{array}$ & $\begin{array}{l}38(52 \cdot 1) \\
15(20 \cdot 5)\end{array}$ & $\begin{array}{r}32(43 \cdot 8) \\
8(11 \cdot 0)\end{array}$ & $\begin{array}{l}\text { NS } \\
\text { NS }\end{array}$ \\
\hline $\begin{array}{l}\text { House dust mite alone } \\
\geqslant 1 \text { positive tests } \\
\geqslant 2 \text { positive tests } \\
\text { Personal atopy (eczema and/or positive skin tests) }\end{array}$ & $\begin{array}{l}5(6 \cdot 8) \\
19(29) \cdot 2) \\
11(16 \cdot 9) \\
27(37 \cdot 0)\end{array}$ & $\begin{array}{r}5(6 \cdot 8) \\
11(15 \cdot 3) \\
5(6 \cdot 8) \\
15(20 \cdot 5)\end{array}$ & $\begin{array}{l}\text { NS } \\
\mathbf{p}<0.05 \\
\text { NS } \\
\mathrm{p}<0.05\end{array}$ \\
\hline
\end{tabular}

were also troubled with coughing. In the index group, $39.5 \%$ of those who had been RSV positive reported subsequent wheezing, compared with $36 \cdot 8 \%$ of those who were RSV negative, thus demonstrating no difference between the two groups.

Upper respiratory tract infections (URTI) were reported as precipitants of wheezing in all symptomatic children (index and control). In addition, $18(24 \cdot 7 \%)$ of the index group and seven $(9.6 \%)$ of controls reported exerciseinduced wheezing $(p<0.05)$. Allergen associated wheezing provoked by animals, grasses or food, was reported in five $(6.8 \%)$ of the index children and two $(2 \cdot 7 \%)$ of controls. This difference was not significant. Wheezing only in association with URTIs and/or changes in the weather was reported in $13(17 \cdot 8 \%)$ of the index children and three $(4 \cdot 1 \%)$ of controls $(p<0 \cdot 01)$.

There was a highly significant difference in the number of index children who used bronchodilator therapy over the previous year (32.9\% of index children compared with $5 \cdot 5 \%$ of controls, $\mathrm{p}<0.0001$ ). Significant differences were also seen in the numbers who were prescribed antibiotics for respiratory symptoms. More of the index children were on asthma prophylactic therapy (sodium cromoglycate or beclomethasone dipropionate), $9 \cdot 6 \%$ compared with $4 \cdot 1 \%$, but this difference failed to reach significance. The parents of index children reported significantly more URTIs and general practitioner consultations for respiratory illness in the past year, compared with the controls.

Index children reported persistent or recurrent nasal blockage in $34 \%$ of cases compared with $11 \%$ of controls, which was a highly significant difference. Of the 73 children who were seen at the 5.5 year follow up, 70 of these had been reviewed two years earlier. At that time, $39(55 \cdot 7 \%)$ were having wheezing episodes. Over the subsequent two year period, 14 of these had become wheeze free, and four children began wheezing when they had not been troubled previously. Thus, there remained a significant overall reduction of $25.6 \%$ in the reporting of wheezing between the two visits $(\mathrm{p}<0.0001)$. As regards coughing episodes, 36 $(51 \cdot 4 \%)$ reported coughing at both visits. By the 5.5 year follow up, 13 children who had previously had coughing were no longer troubled, but 10 were coughing when they had not previously done so. Thus, there was no overall significant reduction.

The frequency of asthma in first degree relatives was identical in the two groups (table 3). There was no significant difference in the incidence of asthma, eczema, or hayfever between index and controls in first degree relatives $(52 \cdot 1 \% v 43 \cdot 8 \%$ respectively). Eczema was more commonly reported in the index children, but this was not significant. However, significantly more children had one or more positive skin test results in the index group ( $29 \cdot 2 \%$ compared with $15 \cdot 3 \%$ in controls) and when eczema and/or positive skin tests were combined as an index of personal atopy, this also was significantly more prevalent in the index group. Thus, personal atopy was related to bronchiolitis in our cohort.

When the relationship between bronchiolitis and subsequent wheezing was studied (table 4) the findings were interesting. Among the index children with positive skin tests, $47 \cdot 4 \%$ of them had subsequent wheezing. However, $41 \cdot 3 \%$ of those who did not have positive skin tests also reported wheezing. This suggests that atopy does not account for the high prevalence of wheezing $5 \cdot 5$ years after bronchiolitis.

The effects of parental smoking and breast feeding were also examined (table 5). Paternal smoking appeared to have no effect on the relative risk of wheezing before bronchiolitis. Children in the index group who had smoking mothers had a relative risk of $4 \cdot 1$ for wheezing compared with 1.8 for those with non-smoking mothers. This suggests that maternal smoking may be influencing the rate of wheezing after

Table 4 Children reporting wheezing related to atopic background. Figures are number (\%) in each group, and relative p values

\begin{tabular}{|c|c|c|c|c|}
\hline $\begin{array}{l}\text { Wheezing children as proportion } \\
\text { of total with: }\end{array}$ & Bronchiolitis & Controls & $\begin{array}{l}\text { Relative } \\
\text { risk }\end{array}$ & $\begin{array}{l}\text { pValue } \\
a v b\end{array}$ \\
\hline $\begin{array}{l}\text { Positive family history of asthma } \\
\text { Negative family history of asthma }\end{array}$ & $\begin{array}{l}\text { (a) } 11 / 18(61 \cdot 1) \\
\text { (c) } 20 / 55(36 \cdot 4) \\
\text { (a) } v \text { (c) NS }\end{array}$ & $\begin{array}{l}\text { (b) } 7 / 18(38.9) \\
\text { (d) } 4 / 55(7.3) \\
\text { (b) } v(\text { d }) \text { p }<0.01\end{array}$ & $\begin{array}{l}1 \cdot 6 \\
5 \cdot 0\end{array}$ & $\begin{array}{l}\text { NS } \\
\mathrm{p}<0.001\end{array}$ \\
\hline Positive family history of asthma, & (a) $21 / 38(55 \cdot 3)$ & (b) $10 / 32(31 \cdot 3)$ & $1 \cdot 8$ & $p=0.08 \mathrm{NS}$ \\
\hline $\begin{array}{l}\text { Negative family history of asthma, } \\
\text { eczema, or hayfever }\end{array}$ & $\begin{array}{l}\text { (c) } 10 / 35(28.6) \\
\text { (a) } v(\text { c) } \mathrm{p}<0.05\end{array}$ & $\begin{array}{l}\text { (d) } 1 / 41(2.4) \\
\text { (b) } v \text { (d) } \mathrm{p}<0.01\end{array}$ & 11.9 & $\mathrm{p}<0.01$ \\
\hline $\begin{array}{l}\text { Eczema } \\
\text { No eczema }\end{array}$ & $\begin{array}{l}\text { (a) } 10 / 15(66 \cdot 7) \\
\text { (c) } 21 / 58(36 \cdot 2) \\
\text { (a) } v(\text { c) NS }\end{array}$ & $\begin{array}{l}\text { (b) } 4 / 8(50) \\
\text { (d) } 7 / 65(10 \cdot 8) \\
\text { (b) } v(\text { d }) \mathrm{p}<0.05\end{array}$ & $\begin{array}{l}1 \cdot 3 \\
3 \cdot 4\end{array}$ & $\begin{array}{l}\text { NS } \\
p<0.001\end{array}$ \\
\hline $\begin{array}{l}\text { Positive skin tests ( } 1 \text { or more) } \\
\text { No positive skin tests }\end{array}$ & $\begin{array}{l}\text { (a) } 9 / 9(47 \cdot 4) \\
\text { (c) } 19 / 6(41 \cdot 3) \\
\text { (a) } v \text { (c) NS }\end{array}$ & $\begin{array}{l}\text { (b) } 5 / 11(45 \cdot 5) \\
\text { (d) } 5 / 16(8 \cdot 2) \\
\text { (b) } v \text { (d) } \mathrm{p}<0.01\end{array}$ & $\begin{array}{l}1 \cdot 0 \\
5 \cdot 0\end{array}$ & $\begin{array}{l}N S \\
p=0.0001\end{array}$ \\
\hline $\begin{array}{l}\text { Personal atopy (eczema/skin tests positive } \\
\text { No personal atopy }\end{array}$ & $\begin{array}{l}\text { (a) } 14 / 27(51 \cdot 9) \\
\text { (c) } 16 / 42(38 \cdot 1) \\
\text { (a) } v(\text { c) NS }\end{array}$ & $\begin{array}{l}\text { (b) } 5 / 15(33.3) \\
\text { (d) } 5 / 57(8.8) \\
\text { (b) } v \text { (d) } \mathrm{p}<0.05\end{array}$ & $\begin{array}{l}1 \cdot 6 \\
4 \cdot 3\end{array}$ & $\begin{array}{l}\mathrm{NS} \\
\mathrm{p}=0.0001\end{array}$ \\
\hline $\begin{array}{l}\text { Positive personal or family history of atopy } \\
\text { No personal or family history of atopy }\end{array}$ & $\begin{array}{l}\text { (a) } 25 / 48(52 \cdot 1) \\
\text { (c) } 6 / 23(26 \cdot 1) \\
\text { (a) } v(\text { c) } p<0.05\end{array}$ & $\begin{array}{l}\text { (b) } 10 / 38(26 \cdot 3) \\
\text { (d) } 1 / 35(2 \cdot 9) \\
\text { (b) } v(\text { d }) \mathrm{p}<0.05\end{array}$ & $\begin{array}{l}2 \cdot 0 \\
9 \cdot 0\end{array}$ & $\begin{array}{l}\mathrm{p}<0.05 \\
\mathrm{p}<0.05\end{array}$ \\
\hline
\end{tabular}


Table 5 Children reporting wheezing related to parental smoking and breast feeding. Figures are number $(\%)$ in each group

\begin{tabular}{|c|c|c|c|c|}
\hline $\begin{array}{l}\text { Wheezing children as } \\
\text { proportion to total with: }\end{array}$ & Index & Controls & $\begin{array}{l}\text { Relative } \\
\text { risk }\end{array}$ & p Value \\
\hline $\begin{array}{l}\text { Smoking mothers } \\
\text { Non-smoking mothers }\end{array}$ & $\begin{array}{r}\text { (a) } 20 / 40(50 \cdot 0) \\
\text { (c) } 11 / 33(33 \cdot 3) \\
\text { (a) } v(\text { (c) NS }\end{array}$ & $\begin{array}{l}\text { (b) } 5 / 41(12 \cdot 2) \\
\text { (d) } 6 / 32(18 \cdot 8) \\
\text { (b) } v \text { (d) NS }\end{array}$ & $\begin{array}{l}4 \cdot 1 \\
1 \cdot 8\end{array}$ & $\begin{array}{l}\mathrm{p}<0.001 \\
0.29 \mathrm{NS}\end{array}$ \\
\hline $\begin{array}{l}\text { Smoking fathers } \\
\text { Non-smoking fathers }\end{array}$ & $\begin{array}{r}\text { (a) } 16 / 35(45 \cdot 7) \\
\text { (c) } 15 / 38(39 \cdot 5) \\
\text { (a) } v \text { (c) NS }\end{array}$ & $\begin{array}{l}\text { (b) } 6 / 39(15 \cdot 4) \\
\text { (d) } 5 / 34(14 \cdot 7) \\
\text { (b) } v \text { (d) NS }\end{array}$ & $\begin{array}{l}3 \cdot 0 \\
2 \cdot 7\end{array}$ & $\begin{array}{l}\mathrm{p}<0.01 \\
\mathrm{p}<0.05\end{array}$ \\
\hline $\begin{array}{l}\text { Breast fed } \\
\text { Not breast fed }\end{array}$ & $\begin{array}{r}\text { (a) } 14 / 30(46 \cdot 7) \\
\text { (c) } 17 / 43(39 \cdot 5) \\
\text { (a) } v \text { (c) NS }\end{array}$ & $\begin{array}{l}\text { (b) } 3 / 27(11 \cdot 1) \\
\text { (d) } 8 / 46(16 \cdot 4) \\
\text { (b) } v \text { (d) NS }\end{array}$ & $\begin{array}{l}4 \cdot 2 \\
2 \cdot 3\end{array}$ & $\begin{array}{l}\mathrm{p}<0.01 \\
\mathrm{p}<0.05\end{array}$ \\
\hline
\end{tabular}

Table 6 Lung function results. Values expressed as \% predicted for height and shown as mean $(S D)$

\begin{tabular}{llll}
\hline & Bronchiolitis & Controls & $p$ Value \\
\hline Peak expiratory flow rate $_{\text {FEV }}$ & $96 \cdot 2(15 \cdot 0)[n=62]$ & $97 \cdot 8(14 \cdot 2)[n=68]$ & NS \\
FEV $_{0 \cdot 75}$ & $96 \cdot 4(16 \cdot 9)[n=61]$ & $10 \cdot 1(18 \cdot 2)[n=67]$ & NS \\
\hline
\end{tabular}

bronchiolitis. However, when the rate of wheezing in the index group with and without smoking mothers was compared $(50.0 \% v$ $33.3 \%$ ), this relationship was not significantly different. Surprisingly, those who had been breast fed had a higher relative risk for wheezing than those who were not $(4.2 v 2.3)$, suggesting that breast feeding does not protect against postbronchiolitis wheezing.

In a stepwise logistic regressional model, parental smoking, breast feeding, family history of atopy, personal atopy, family size, and social class were included. Having taken all these factors into account, bronchiolitis significantly improved the prediction of wheezing when added to the model $(p<0.005)$. When considering the index and control groups together, the factors that were significantly associated with wheezing overall, were family and personal history of atopy and bronchiolitis. Therefore, further analysis was performed looking only at these significant factors. In this model, bronchiolitis remained a significant predictor of wheezing $(p=0.001)$.

There was a non-significant trend for mean $\mathrm{FEV}_{1}$, and mean $\mathrm{FEV}_{0.75}$ to be lower in the index group (table 6). The difference in lung function results in those reporting wheezing compared with those who did not, also failed to reach statistically significant levels. Also, atopic children did not have significantly different lung function to non-atopic children in each group.

Histamine challenges were performed on 47 $(64 \cdot 4 \%)$ of the index group and $58(79 \cdot 5 \%)$ of the controls. Histamine challenges were not performed for the reasons shown in table 7 . A

Table 7 Reasons for not performing histamine challenges. Figures are number (\%)

\begin{tabular}{lll}
\hline & Bronchiolitis & Controls \\
\hline Lung function not reproducible & $9(12 \cdot 3)$ & $4(5 \cdot 5)$ \\
Unwilling & $8(11 \cdot 0)$ & $5(6 \cdot 8)$ \\
Home visit & $5(6 \cdot 8)$ & $3(4 \cdot 1)$ \\
Symptomatic (wheezy) & $3(4 \cdot 1)$ & $1(1 \cdot 4)$ \\
URTI & $1(1 \cdot 4)$ & $2(2 \cdot 7)$ \\
Total & $26 / 73(35 \cdot 5)$ & $15 / 73(20 \cdot 5)$ \\
\hline
\end{tabular}

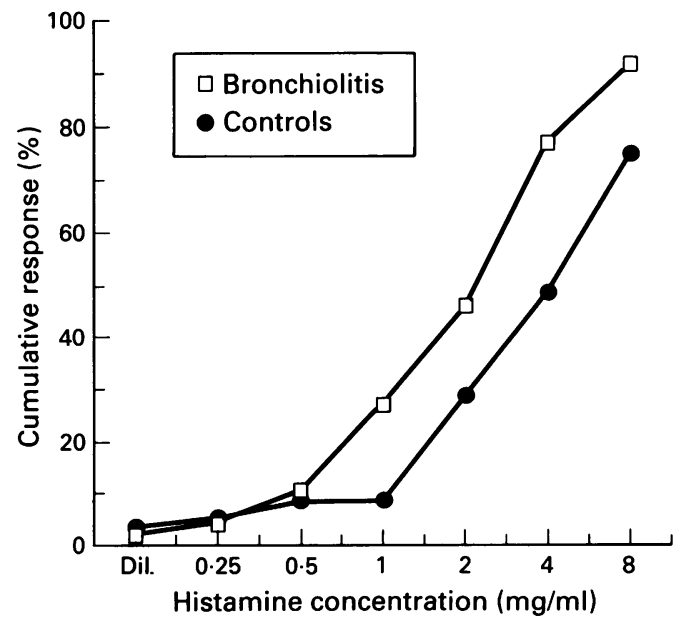

Histamine challenge results.

Table 8 Bronchial responsiveness to histamine. Figures are number (\%)

\begin{tabular}{llc}
\hline $\begin{array}{l}\text { Provocative } \\
\text { concentration }\end{array}$ & $\begin{array}{l}\text { Bronchiolitis } \\
(n=47)\end{array}$ & $\begin{array}{l}\text { Controls } \\
(n=58)\end{array}$ \\
\hline $\begin{array}{l}\text { Histamine } \leqslant 1 \mathrm{mg} / \mathrm{ml} \\
(\text { moderate-severe response) }\end{array}$ & $12(25 \cdot 5)$ & $3(5 \cdot 2)$ \\
$\begin{array}{l}\text { Histamine }>1 \mathrm{mg} / \mathrm{ml} \\
\text { (mild response } \leqslant 4 \mathrm{mg} / \mathrm{ml})\end{array}$ & $24(51 \cdot 1)$ & $24(41 \cdot 4)$ \\
$\begin{array}{l}\text { Histamine }>4 \mathrm{mg} / \mathrm{ml} \\
\text { (slight or no response) }\end{array}$ & $11(23 \cdot 4)$ & $31(53 \cdot 4)$ \\
\hline
\end{tabular}

high rate of histamine responsiveness was noted in the index group (table 8 ) with $77 \%$ having a $\mathrm{PC}_{20}$ of less than or equal to $4 \mathrm{mg} / \mathrm{ml}$ compared with $47 \%$ of the controls $(p<0 \cdot 01)$. From the graph of the cumulative response to histamine it can be seen that there is a high rate of responsiveness in both groups, with the bronchiolitis group showing an excess of moderate responders, with no excess at concentrations of less than $0.5 \mathrm{mg} / \mathrm{ml}$ (figure).

\section{Discussion}

Two problems associated with a long term follow up such as this are, first, the number of the index children who cannot be traced and, secondly, providing a well matched control group. We were unable to trace 21 of the original 101 children. Attempts were made to phone those families who had failed to attend after at least two letters inviting them to come up with their children for assessment. When this too failed, the last known addresses of the families were visited. Wherever possible, we obtained forwarding addresses either from the present occupants, from local shops, or from the general practitioner. A further five were excluded on account of other neurological or cardiovascular disease, and two on the basis that the initial diagnosis was in doubt. An essential requirement for inclusion in the study was the presence of fine crepitations on auscultation on at least one occasion while in hospital. This undoubtedly excluded some children who had classic RSV bronchiolitis, but greatly reduced the chance of recruiting asthmatic infants whose acute attack was triggered by an RSV infection. 
In these two children, we were unable to find any documentary evidence that they had ever had fine crepitations on auscultation.

The selection of a suitable control group also presented considerable problems. Ideally, we wished for the index and control children to be matched in all aspects apart from a previous episode of acute bronchiolitis. Selecting control children from birth records was considered but rejected on grounds that previous studies had shown an increased prevalence of parental smoking and low social class in those requiring admission for acute bronchiolitis. The groups were also matched very closely for breast feeding, the absence of this parameter being a criticism which had been levied against studies in the past.

We considered matching each index child with a control from his own class, but this proved impracticable, and so as a compromise, we selected schools close to the hospital, which were attended by the majority of the index cases. The children were then selected on birth date, sex, race, area, and maternal smoking. The led to very close matching for social class, parental as well as maternal smoking, breast feeding, and the incidence of prematurity. The control children as a group were significantly taller than the index children but were also 4 months older. Thus, their height centiles were not significantly different.

As previous studies have shown, there was a considerable excess of respiratory symptoms in the index cases, who had three times as much wheezing and twice as many coughing episodes as the controls. Those who were classified as RSV negative in the acute episode, as a result of immunofluorescent and paired serum, had the same pattern of symptomatology as those who were RSV positive. The high proportion of index children receiving both bronchodilator and prophylactic treatment, may well be related to their inclusion in this ongoing follow up study, but must to some extent be dependent on the frequency and severity of the symptoms in the index children. Although the overall prevalence of wheezing had fallen by $25 \%$ since the previous review 3.5 years after bronchiolitis, the prevalence of coughing was unchanged.

The frequency of asthma and other atopic symptoms was remarkably similar in the families of the index and the control groups, providing further evidence that those babies requiring admission to hospital with bronchiolitis do not have a genetic predisposition to asthma or increased bronchial reactivity. The data on personal atopy, was to some extent in conflict with this. There was a trend for more index children to have eczema and skin tests were significantly more likely to be positive in the index compared with the control group, the reverse of that found in the study by Pullan et $a l .{ }^{4}$ We have no adequate explanation for this discrepancy. In our cohort, babies were recruited who had the clinical features of acute bronchiolitis, whereas the Pullan study was restricted to those who were RSV positive. Inevitably, the index group would have included some babies destined to develop asthma and it is possible that in an attempt to avoid including babies who had had acute bronchiolitis in the control group, we excluded some who had infantile asthma. The number of babies excluded from the control group on these grounds was very small and not sufficient to explain the different prevalences of atopy.

Moreover, surprisingly, those children who had positive skin tests were no more likely to wheeze than those who had negative ones, again, suggesting that atopy was not an important cause of respiratory symptoms in the index children. Maternal but not paternal smoking was associated with an increased incidence of wheezing, but were were unable to show that breast feeding had a protective effect for postbronchiolitic wheezing. Stepwise logistic regression analysis showed that acute bronchiolitis in infancy continued to have a highly significant effect on the incidence of wheezing, once maternal smoking, breast feeding, personal atopy, family size and social class, had been taken into account. A further analysis looking purely at family and personal history of atopy and bronchiolitis, again showed that bronchiolitis was acting as an independent factor, strongly supporting the contention that acute bronchiolitis is generating a state of abnormal bronchial reactivity in the airways rather than acting as a marker for children who have an inherent asthma tendency.

Baseline lung function tests were not particularly discriminatory but the histamine challenges did produce some interesting results. The incidence of extreme histamine sensitivity was very similar in the two groups. The main differences occurring in those who were moderately sensitive. We were concerned about the high incidence of positive responses in the controls, but this pattern of increased sensitivity in the young has previously been well documented.

From this study we conclude that although the incidence of wheezing falls in the fourth to sixth year after acute bronchiolitis, these symptoms remain considerably more frequent than in controls. Although the index children had more personal atopy, this was not related to respiratory symptoms. The data lends support to the hypothesis that acute RSV bronchiolitis is responsible for the production of an asthma syndrome which can persist for many years after the acute infection.

We gratefully acknowledge financial help from the National Asthma Campaign.

1 Sim DG, Downham MAPS, Gardner PS, Webb JKG, Weightman D. Study of 8 year old children with a history of respiratory syncytial virus bronchiolitis in infancy. $B M \mathcal{F}$ 1978; i: $11-4$.

2. Duiverman EJ, Neijens HJ, Van Strik R, Affourht MJ, Kerrebijn KF. Lung function and bronchial responsiveness in children who had infantile bronchiolitis. Pediatr Pulmonol 1987;3:38-44.

3 Gurwitz D, Levison $H$. Increased incidence of bronchial reactivity in children with a history of bronchiolitis. f Pediatr 1981;98:551-5.

4 Pullan CR, Hey EN. Wheezing, asthma and pulmonary dysfunction 10 years after infection with respiratory syncytial virus in infancy. $B M \mathcal{F} 1982 ; 284: 1665-9$.

5 Sly PN, Hibbert ME. Childhood asthma following hospitalisation with acute viral bronchiolitis in infancy. Pediatr Pulmonol 1989;7:153-8.

6 Henry RL, Hodges IGC, Milner AD, Stokes GM. Respiratory problems two years after acute bronchiolitis in infancy. Arch Dis Child 1983;58:713-6.

7 Webb MSC, Henry RL, Milner AD, Stokes GM, Swarbrick AS. Continuing respiratory problems three and a half years 
after acute viral bronchiolitis. Arch Dis Child 1985;60: 1064-7.

8 Kattan M, Keens TG, Lapierre JG, Levison H, Bryan AC, Reilly BJ. Pulmonary function abnormalities in symptomfree children after bronchiolitis. Pediatrics 1977;59:683-8

9 Wittig HJ, Cranford NJ, Glaser J. The relationship between bronchiolitis and childhood asthma. A follow-up study of 100 cases of bronchiolitis in infancy. $\mathcal{f}$ Allergy 1959;30: 19-23.

10 Eisen AH, Bacal JL. The relationship of acute bronchiolitis to bronchial asthma: a 4-14 year follow up. Pediatrics 1963;31:859-61.

11 Rooney JC, Williams HE. The relationship between proved viral bronchiolitis and subsequent wheezing. $\mathcal{F}$ Pediat 1971;79:744-7.

12 Twiggs JT, Larsen LA, O'Connell ES, Illstrup DM. Respiratory syncytial virus infection. Clin Pediatr (Phila) 1981;10. $187-90$

13 Mok JYQ, Simpson H. Outcome of acute lower respiratory infection in infants: preliminary report of seven-year follow-up study. $B M \mathcal{F}$ 1982;285:33-7.

14 Mok JYQ, Simpson H. Symptoms, atopy and bronchia reactivity after lower respiratory infection in infancy. Arch Dis Child 1984;59:299-305.

15 Zweiman B, Schoenwetter WF, Pappano JE, Tempest B, Hildreth EA. Patterns of allergic respiratory disease in children with a past history of bronchiolitis. $\mathcal{f}$ Allergy Clin Immunol 1971;48:283-9.

16 Laing I, Riedel F, Yap PL, Simpson H. Atopy predisposing to acute bronchiolitis during an epidemic of respiratory to acute bronchiolitis during an epidemic
syncytial virus. $B M \mathcal{F} 1982 ; 284: 1070-2$.
17 Carlson KH, Larsen S, Orstavik I. Acute bronchiolitis in infancy. The relationship to later recurrent obstructive airways disease. European fournal of Respiratory Diseases 1987;70:86-92.

18 Rylander E, Eriksson M, Freyschuss U. Risk factors for occasional and recurrent wheezing after RSV infection in infancy. Acta Paediatr Scand 1988;77:711-5.

19 Carlsen K, Larsen S, Bjerve O, Leegaard J. Acute bronchiolitis: predisposing factors and characterisation of infants at risk. Pediatr Pulmonol 1987;3:153-60.

20 McConnochie KM, Roghmann KJ. Bronchiolitis as a possible cause of wheezing in childhood: new evidence. Pediatrics cause of wheez

21 McConnochie KM, Roghmann KJ. Wheezing at 8 and 13: changing importance of bronchiolitis and passive smoking. changing importance of bronchio

22 Samet JM, Tager IB, Speizer FE. The relationship between respiratory illness in childhood and chronic airflow obstrucion in adulthood. Am Rev Respir Dis 1983;127:508-23.

23 Colley JRT, Douglas JWB, Reid DD. Respiratory disease in young adults: influence of early childhood lower respiratory tract illness, social class, air pollution and smoking. $B M$ 1973;iii:195-8.

24 Phelan PD. Does adult chronic obstructive lung disease really begin in childhood? $\mathrm{Br} \mathcal{F}$ Dis Chest 1984;78:1-9.

25 Tipton WR. Evaluation of skin testing in the diagnosis of gE-mediated disease. Pediatr Clin North Am 1983;30: 785-93.

26 Cockcroft DW, Killian DN, Mellon JJA, Hargreave FE. Bronchial reactivity to histamine: a method and clinical survey. Clin Allergy 1977;7:235-43. 